\title{
Congenital Urinary Tract Obstruction
}

National Cancer Institute

\section{Source}

National Cancer Institute. Congenital Urinary Tract Obstruction. NCI Thesaurus. Code C123157.

An impediment to the flow of urine along the urinary tract, which is present at birth. 